\title{
Effects of Short-Term Exercise on Adiponectin and Adiponectin Receptor Levels in Rats
}

\author{
Qin Zeng, Ling Fu, Kazuhiro Takekoshi, Yasushi Kawakami, and Kazumasa Isobe
}

Graduate School of Comprehensive Human Sciences, University of Tsukuba, Ibaraki, Japan.

\begin{abstract}
Aim: Adiponectin reportedly reduces insulin resistance. Exercise has also been shown to lessen insulin resistance, although it is not well known whether exercise increases levels of adiponectin and/or its receptors nor whether it effects are dependent on exercise intensity and/or period. We previously reported that blood adiponectin levels increased by $150 \%$ in animals that exercised at a rate of 30 $\mathrm{m} / \mathrm{min}$ for 60 minutes, 2 days per week, and adiponectin receptor 1 (AdipoR1) mRNA levels in muscle increased up to 4 times in response to exercise at a rate of $25 \mathrm{~m} / \mathrm{min}$ for $30 \mathrm{~min}, 5$ days per week for 12 weeks.

Methods: In light of this information, we examined the effects of short-term exercise on adiponectin, and adiponectin receptor levels in rats, using ELISA and real-time PCR.

Results: Our data showed that adiponectin mRNA levels in adipose tissue increased by $280 \%$ in rats exercised at a rate of $30 \mathrm{~m} / \mathrm{min}$ for 60 minutes for 2 weeks and correlated with the exercise time periods. No effects of short-term exercise on adiponectin receptor $1 \mathrm{mRNA}$ in muscle were observed.

Conclusion: Thus, long-term exercise may be required to regulate adiponectin receptor $1 \mathrm{mRNA}$ expression in muscle and adiponectin mRNA expression in adipose tissue.
\end{abstract}

J Atheroscler Thromb, 2007; 14:261-265.

Key words; Adiponectin, Adiponectin receptor, Adrenaline, Short-term exercise

\section{Introduction}

Adiponectin is a protein hormone produced and secreted exclusively by adipocytes that regulates the metabolism of lipids and glucose, and which has antiinflammatory properties. It has been reported to play a role in the development of cardiovascular disease, type 2 diabetes, and obesity, and its levels have been shown to be suppressed in insulin-resistant and obese animals and humans ${ }^{1-3)}$. Two types of adiponectin receptors have been identified i.e., adiponectin receptor 1 (AdipoR1) and adiponectin receptor 2 (AdipoR2), which are primarily expressed in muscle and liver cells, respectively ${ }^{4)}$. It has also been reported that the expressions of AdipoR1/R2 in ob/ob mice were significantly decreased in skeletal muscle and adipose tissue ${ }^{5)}$.

Address for correspondence: Kazumasa Isobe, Department of Clinical Pathology, Institute of Clinical Medicine, University of Tsukuba, 1-1-1 Tenoudai, Tsukuba, 305-8575, Japan.

E-mail: k-isobe@md.tsukuba.ac.jp

Received: January 19, 2007

Accepted for publication: April 6, 2007
Adiponectin levels were reported to rise in response to weight loss and glitazone therapy, but not after chronic exercise training ${ }^{6-8)}$. On the other hand, Bluher et al. reported that 4-week physical training increased circulating adiponectin levels and Kriketos et al. also reported that one week of exercise training showed a similar effect ${ }^{9,10)}$. Jurimae et al. reported that adiponectin levels were modulated in response to a single cycle of maximal exercise in highly trained male rowers ${ }^{11}$, although others failed to find such an effect in healthy subjects ${ }^{12}$. Yokoyama et al. reported that aerobic exercise did not alter plasma adiponectin levels in overweight, insulin-resistant, nondiabetic individuals ${ }^{13)}$, similar to findings reported by Marcel et al. who failed to find an effect of moderate to intense exercise on adiponectin levels or insulin sensitivity in type 2 diabetics ${ }^{14)}$. Recently, it has been reported that adiponectin levels are independently related to physical exercise $^{15)}$. Adiponectin receptor levels were reported to rise after chronic exercise training ${ }^{10,11,16)}$. On the other hand, Punyadeera et al. and Marcell et al. reported that they failed to find such an effect ${ }^{14,17)}$. 
Thus, the effect of exercise on adiponectin or adiponectin receptors levels is still unclear, although the data perhaps suggest that intense exercise is more likely to influence adiponectin levels. The mechanisms by which adiponectin levels are regulated during exercise are unknown. We previously reported that blood adiponectin levels increased by $150 \%$ in animals that exercised at a rate of $30 \mathrm{~m} / \mathrm{min}$ for $60 \mathrm{~min} 2$ days per week for 12 weeks and that AdipoR1 mRNA levels in muscle increased up to 4 times by exercise at a rate of $25 \mathrm{~m} / \mathrm{min}$ for 30 min 5 days per week for 12 weeks ${ }^{18)}$. In this study, we examined the effects of short-term exercise on blood adiponectin, adiponectin mRNA and tumor necrosis factor $\alpha(\mathrm{TNF} \alpha)$ in adipose tissue, adiponectin receptor mRNA in muscle tissue, urinary catecholamine, and blood lipids levels.

\section{Materials and Methods}

\section{Animals}

All experimental procedures involving animals were approved by the University of Tsukuba Animal Care and Use Committee. Twenty, eight-week-old male SD rats were randomly assigned to either a sedentary control group $(n=5)$ or exercise training groups $(n=5$ for each exercise regimen, 3 days or 5 days/wk for one or two weeks, at $30 \mathrm{~m} / \mathrm{min}$ for $60 \mathrm{~min}$ ). Rats were housed and maintained in a temperature-controlled room $\left(22 \pm 2^{\circ} \mathrm{C}\right)$ on a $12: 12$-h light-dark cycle $(0600$ to 1800), with food and water ad libitum. Exercise training sessions of $60 \mathrm{~min}$ were carried out just before the beginning of the dark cycle in the room where the animals were housed. Animals were weighed at the beginning and end of the study, and sacrificed by blood harvesting after anesthetization.

\section{Exercise Training Protocol}

Animals exercised for 3 days or 1 or 2 weeks using the following regimens: $30 \mathrm{~m} / \mathrm{min}$ for $60 \mathrm{~min}$ on a motor-driven treadmill. Both the treadmill speed and grade were gradually increased over the course of the training period to provide training overload throughout the training regimen. This training intensity was designed to elicit $75 \%$ (30 m/min for $60 \mathrm{~min}$ ) maximal oxygen uptake based on previous work in adult rats ${ }^{18)}$.

\section{Tissue Samples}

Animals were terminally anesthetized with dieth$\mathrm{yl}$ ether and sodium pentobarbital $(50 \mathrm{mg} / \mathrm{kg}$ ip), after which blood was harvested from the abdominal aorta. The soleus muscle, liver and adipose tissue from the epididymal fat pad were quickly removed, and the tissues were then quickly frozen by immersion in liquid nitrogen. Tissues and sera were stored at $-80^{\circ} \mathrm{C}$ until use.

\section{Determination of Adiponectin and Catecholamine Levels}

Plasma adiponectin concentration was determined by ELISA (Otsuka Pharmaceutical, Tokyo, Japan). Urine samples were collected for 24 hours after exercise (1800 to 1800 the next day). Urine catecholamine (adrenaline, noradrenaline, dopamine) concentrations were determined using a catecholamine autoanalyzer (HLC-725CA, TOSOH, Tokyo).

\section{Real-Time PCR}

Adiponectin and TNF $\alpha$ mRNA expressions in adipose tissue were assessed using the Assay-on-demand protocol (Applied Biochemistry, Foster City, Calif.) that was prepared using a TaqMan PCR master reagent kit. TaqMan ${ }^{\circledR}$ Assay-on-demand was also used to determine adiponectin receptor $1 \mathrm{mRNA}$ expression in muscles. The thermal cycling protocol was $2 \mathrm{~min}$ at $50^{\circ} \mathrm{C}$ and $10 \mathrm{~min}$ at $95^{\circ} \mathrm{C}$, followed by 40 cycles of $95^{\circ} \mathrm{C}$ for $15 \mathrm{~s}$ and $60^{\circ} \mathrm{C}$ for $1 \mathrm{~min}$. Thermal cycling, fluorescence detection, and data analysis were performed on an ABL PRISM 7900 Sequence Detector using the software provided with the instrument. Adiponectin, TNF $\alpha$ and AdipoR1 mRNA levels were normalized to those of GAPDH mRNA.

\section{Statistics}

All values are expressed as the mean \pm SE. Catecholamine values were examined after logarithm transformation. Statistical significance was determined by analysis of variance (ANOVA). Tukey-Kramer post hoc comparisons were used to determine the source of significant differences where appropriate. Pearson's correlation test was used to examine relationships between variables. A $p$ value $<0.05$ was considered significant.

\section{Results}

\section{Body Weights}

As shown in Table 1, exercise-trained animals in this study did not show a significant difference compared to the control group in body weight, suggesting that 3 days to 2 weeks of exercise may not affect the adipose tissue weight of rats.

\section{Adiponectin Levels}

As shown in Fig. 1, rats in the 2-week group displayed adiponectin mRNA levels in adipose tissue that were 2.8 times higher than in controls $(p<0.05)$. Adiponectin and TNF $\alpha$ were reported to inhibit each 
Table 1. Effects of 3 days, 1 week and 2 weeks of training on initial and final body weight

\begin{tabular}{lcccc}
\hline \multicolumn{3}{c}{ initial $(\mathrm{g})$} & \multicolumn{3}{c}{ final $(\mathrm{g})$} \\
\hline control & $(n=5)$ & $378 \pm 19$ & $(n=5)$ & $401 \pm 23(100 \%)$ \\
3 days & $(n=5)$ & $362 \pm 6$ & $(n=5)$ & $368 \pm 5(92 \%)$ \\
1 week & $(n=5)$ & $390 \pm 10$ & $(n=3)$ & $403 \pm 12(110 \%)$ \\
2 weeks & $(n=5)$ & $362 \pm 11$ & $(n=5)$ & $373 \pm 16(93 \%)$ \\
$F$ & & 0.956 & & 1.22 \\
$d f s$ & 3,14 & & 3,14 \\
\hline
\end{tabular}

Data are the means \pm SE. Compared with control. 3 days, 3 days of exercise; 1 week, 5 days of exercise/week for 1 week; 2 weeks, 5 days of exercise/week for 2 weeks. $F, \mathrm{~F}$ value; $d f s$, degree of freedom.

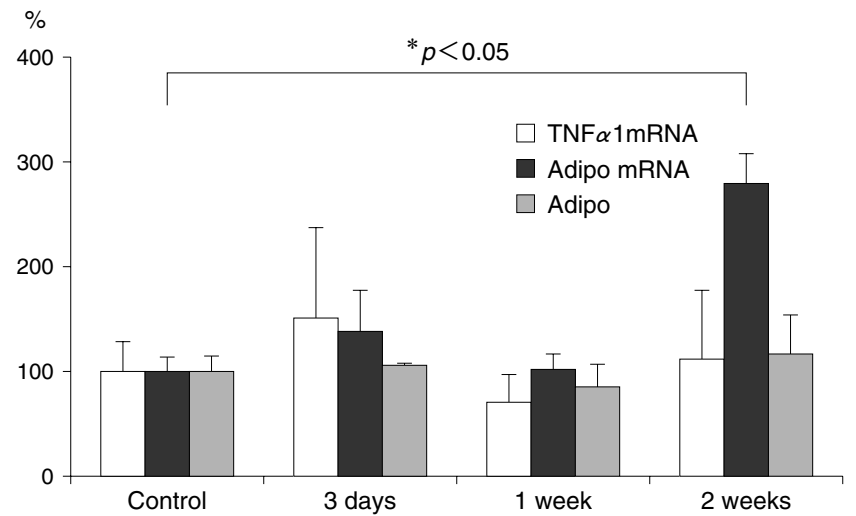

Fig. 1. Effects of 3 days, 1 week and 2 weeks of training on adiponectin and adiponectin, and TNF $\alpha$ mRNA levels in rat adipose tissue.

Each bar represents the $\%$ of controls and is the mean \pm SE. ${ }^{*} p<0.05$ compared with the control group. $F=0.2, d f=3,13$ (adiponectin protein), $F=4.022, d f=3,14$ (adiponectin mRNA), $F=0.62, d f=$ 3, 14 (TNF $\alpha$ mRNA).

Table 2. Effects of one-time training on blood adiponectin levels in rats

\begin{tabular}{cccccc}
\hline \multicolumn{1}{c}{ Unit $/ \mathrm{mL})$} & pretraining & 30 min after training & 2 hour after training & $F$ & $d f s$ \\
\hline 3 days $(n=5)$ & $1,975 \pm 281$ & $1,839 \pm 231$ & $1,929 \pm 275$ & 0.07 & 2,12 \\
1 week $(n=3)$ & $2,667 \pm 184$ & $3,739 \pm 429$ & $3,237 \pm 391$ & 0.18 & 2,6 \\
2 weeks $(n=5)$ & $2,202 \pm 207$ & $2,343 \pm 285$ & $2,569 \pm 294$ & 0.49 & 2,12 \\
\hline
\end{tabular}

Data are the means \pm SE. Compared to pretraining. $F, F$ value; $d f s$, degree of freedom.

Table 3. Effects of 3 days, 1 week, and 2 weeks of training on adiponectin receptor $1 \mathrm{mRNA}$ levels in the muscle of rats

\begin{tabular}{lc}
\hline & Muscle adipo R1 mRNA \\
\hline Control & $38.8 \pm 3.9(100 \%)$ \\
3 days & $30.6 \pm 2.3(79.0 \%)$ \\
1 week & $45.6 \pm 9.8(117 \%)$ \\
2 weeks & $29.5 \pm 2.3(76.0 \%)$ \\
$F$ & 2.269 \\
$d f$ & 3,16 \\
\hline
\end{tabular}

Datas are the means $\pm \mathrm{SE}$. adipo $\mathrm{R} 1$, adiponectin receptor $1 ; F, \mathrm{~F}$ value; $d f$, degree of freedom.

other's production in adipocytes; however, TNF $\alpha$ mRNA expression was not significantly reduced in this time period. The expression of adiponectin level

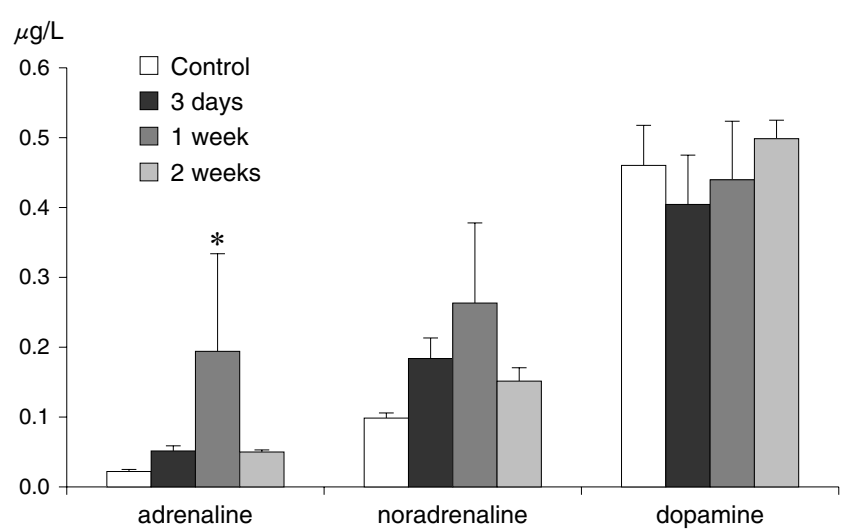

Fig. 2. Effects of 3 days, 1 week and 2 weeks of training on urinary catecholamine levels of exercised rats.

Each bar represents the mean \pm SE. ${ }^{*} p<0.05$ compared with the control group. $F=4.27, d f=3,15$ (adrenaline), $F=1.5, d f=3,15$ (noradrenaline), $F=0.513, d f=3,15$ (dopamine).

was assessed in adipose tissue in order to determine whether the effect of exercise on adiponectin mRNA levels was associated with an increase in adiponectin 
Table 4. Effects of 3 days, 1 week and 2 weeks of training on the blood lipid profile and glucose in rats

\begin{tabular}{lcccccc}
\hline & control & 3 days & 1 week & 2 weeks & $F$ & $d f s$ \\
\hline TG $(\mathrm{mg} / \mathrm{dL})$ & $77.6 \pm 16$ & $30.8 \pm 6.5^{*}$ & $47.1 \pm 11$ & $38.3 \pm 4.9$ & 4.46 & 3,14 \\
TCHO $(\mathrm{mg} / \mathrm{dL})$ & $51.0 \pm 4.7$ & $49.8 \pm 3.1$ & $45 \pm 2.7$ & $58.7 \pm 1.4$ & 2.542 & 3,14 \\
PL $(\mathrm{mg} / \mathrm{dL})$ & $84.4 \pm 3.8$ & $78.2 \pm 4.0$ & $73.1 \pm 2.3$ & $88.3 \pm 2.1$ & 2.019 & 3,14 \\
$\mathrm{GLU}(\mathrm{mg} / \mathrm{dL})$ & $196.6 \pm 9.2$ & $168 \pm 16$ & $162 \pm 20$ & $150 \pm 4.8$ & 2.23 & 3,14 \\
FFA $(\mu \mathrm{EQ} / \mathrm{L})$ & $564 \pm 45.2$ & $502 \pm 51$ & $484 \pm 68$ & $546 \pm 33$ & 0.816 & 3,14 \\
\hline
\end{tabular}

Rats were housed for $48 \mathrm{~h}$ water and food ad libitum after the cesation of training. Data are the means \pm SE. * $p<0.05$, compared with control. TG, triglyceride; TCHO, total cholesterol, PL, phospholipid. GLU, glucose; FFA, free fatty acid. F, F value; $d f$, degree of freedom.

protein; our data could not show a significant difference, but the average adiponectin level in the 2-week group was 1.3 times higher than in the control group. Exercise period correlated with adiponectin mRNA expression $(r=0.641, p<0.005)$.

As shown in Table 2, adiponectin blood levels were not changed after $30 \mathrm{~min}$ or 2 hours in response to a single cycle of maximal exercise, suggesting that plasma adiponectin does not respond to acute exercise in rats.

\section{Adiponectin Receptor Levels}

As shown in Table 3, AdipoR1 mRNA levels in muscle tissues of exercised rats were not significantly different between the groups, suggesting that 3 days to 2 weeks of exercise may not affect AdipoR1 mRNA expression in the muscle of rats.

\section{Catecholamine Levels}

As shown in Fig. 2, rats in the 1-week group displayed significantly higher levels of urinary adrenaline compared to controls $(p<0.05)$, suggesting that 2 -week rats were adapted to exercise. Urinary noradrenaline and dopamine levels were not significantly different between the groups.

\section{Blood Biochemical Parameters}

As shown in Table 4, the serum triglyceride (TG) level in 3-day rats was significantly decreased compared to control rats $(p<0.05)$. The mean values of TG and fasting blood glucose (GLU) were decreased in exercised rats. Total cholesterol (TCHO), phosphor lipids (PL), blood glucose (GLU), and free fatty acid (FFA) levels were not significantly different between the groups.

\section{Discussion}

Our results showed that adiponectin mRNA levels in adipose tissue increased by $280 \%$ in rats exercised at a rate of $30 \mathrm{~m} / \mathrm{min}$ for $60 \mathrm{~min}$ for 2 weeks and were significantly correlated with the exercise time periods; however, adiponectin protein levels in adipose tissue did not increase during the same time period. In our in vitro study using 3T3L1 adipocytes, a 300\% increase in adiponectin mRNA levels induced only a $30 \%$ increase in the protein level (data not shown). In addition, a single exercise session did not affect blood adiponectin levels, as Ferguson et al. reported, suggesting that long-term exercise, longer than 2 weeks, may be needed to increase the protein level ${ }^{19)}$.

We previously reported that AdipoR1 mRNA levels in muscles increased up to 4 -fold in response to exercise at a rate of $25 \mathrm{~m} / \mathrm{min}$ for $30 \mathrm{~min} 5$ days per week for 12 weeks $^{18)}$; however, in this study, we could not observe such an effect with short-term exercise. Kim et al. reported that an increase in muscle adiponectin receptor $1 \mathrm{mRNA}$ was observed in animals that exercised for 3 weeks ${ }^{20)}$. Chang et al. and Huang et al. reported similar results for 8 weeks ${ }^{16,21)}$. Punyadeera $e t$ al. reported that adiponectin receptor $1 \mathrm{mRNA}$ expression in human skeletal muscle was not acutely regulated by exercise ${ }^{17)}$, suggesting that only long-term exercise might increase adiponectin receptor 1 mRNA expression. Taken together, 3 weeks or more of exercise is needed to induce AdipoR1 mRNA expression in muscle tissue.

It is well known that exercise improves insulin resistance and adiponectin is also an important insulinsensitizing cytokine; however, the effect of exercise on adiponectin levels has been controversial until now. One reason why the results of the effects of exercise on adiponectin are variable may be the inhibitory modification by adrenaline released during exercise. It was reported that $\beta$-agonist decreased adiponectin mRNA expression in 3T3L1 adipocytes ${ }^{22}$. In addition, in our study, no increase in adipose tissue adiponectin mRNA was observed while a significant increase in adrenaline level was observed in animals that exercised for 1 week, suggesting that the adrenaline released during exercise may inhibit adiponectin mRNA expression.

In conclusion, our findings suggested that longterm exercise may be required to regulate adiponectin 
receptor $1 \mathrm{mRNA}$ expression in muscle and adiponectin mRNA expression in adipose tissue. We have also suggested that adrenaline might suppress adiponectin mRNA expression in vivo; however, the mechanisms by which adiponectin or adiponectin receptor levels are regulated during exercise are still unknown. Further investigation is required to examine this question.

\section{References}

1) Okamoto A, Arita Y, Nishida M, Muragachi M, Ouchi N, Takahashi M, Igura T, Inui Y, Kihara S, Nakamura T, Yamashita S, Miyagawa J, Funahashi T, and Matsuzawa Y: An adipocyte-derived protein, adiponectin, adheres to injured vascular walls. Horm Metab Res, 2001; 32:47-50

2) Arita Y, Kihara S, Ouchi N, Takahashi M, Maeda K, Miyagawa J, Hotta K, Shimomura I, Nakamura T, Miyaoka K, Kuriyama H, Nishida M, Yamashita S, Okubo K, Matsubara K, Muraguchi M, Ohmoto Y, Funahashi T, and Matsuzawa Y: Paradoxical decrease of an adipose-specific protein, adiponectin, in obesity. Biochem Biophys Res Commun, 1999; 257:79-83

3) Hotta K, Funahashi T, Arita Y, Takahashi M, Motsuda M, Okamoto Y, Iwahashi H, Kuriyama H, Ouchi N, Maeda K, Nishida K, Kihara S, Sakai N, Nzakajima T, Hasegawa K, Muraguchi M, Ohmoto Y, Nakamura T, Yamashita S, Hanafusa T, and Matsuzawa Y: Plasma concentrations of a novel, adipose-specific protein, adiponectin, in type 2 diabetic patients. Arterioscler Thromb Vasc Biol, 2000; 20:1595-1599

4) Yamauchi T, Kamon J, Ito Y, Tsuchida A, Yokomizo T, Kita S, Sugiyama T, Miyagishi M, Hara K, Tsunoda M, Murakami K, Ohtaki T, Uchida S, Takekawa S, Waki H, Tsuno NH, Shibata Y, Terauchi Y, Froguel P, Tobe K, Koyasu S, Taira K, Kitamura T, Shimizu T, Nagai R, and Kadowaki T: Cloning of adiponectin receptors that mediate antidiabetic metabolic effects. Nature, 2003; 423:762-769

5) Kadowaki $T$ and Yamauchi T: Adiponectin and adiponectin receptors. Endocr Rev, 2005; 26:439-451

6) Hulver MW, Zheng D, Tanner CJ, Houmard JA, Kraus WE, Slentz CA, Sinha MK, Pories WJ, MacDonald KG, and Dohn GL: Adiponectin is not altered with exercise training despite enhanced insulin action. Am J Physiol Endocrinol Metab, 2002; 283:E861-865

7) Boudou P, Sobngwi E, Mauvaris-Jarvis F, Vexiau P, and Gautier JF: Absence of exercise-induced variations in adiponectin levels despite decreased abdominal adiposity and improved insulin sensitivity in type 2 diabetic men. Eur J Endocrinol, 2003; 149:421-424

8) Yatagai T, Nishida Y, Nagasaka S, Nakamura T, Tokuyama $\mathrm{K}$, Shindo M, Tanaka H, and Ishibashi S: Relationship between exercise training-induced increase in insulin sensitivity and adiponectinemia in healthy men. Endocrine J, 2003; 50:233-238

9) Blüher M, Bullen JW, Lee JH, Kralisch S, Fasshauer M, Klöting N, Niebauer J, Schön MR, Williams CJ, and
Mantzoros CS: Circulating adiponectin and expression of adiponectin receptors in human skeletal muscle: associations with metabolic parameters and insulin resistance and regulation by physical training. J Clin Endocrinol Metab, 2006; 91:2310-2316

10) Kriketos AK, Gan SK, Poynten AM, Furler SM, Chisholm DJ, and Campbell LV: Exercise increases adiponectin levels and insulin sensitivity in humans. Diabetes Care, 2004; 27:629-631

11) Jürimäe J, Purge $P$, and Jürimäe $T$ : Adiponectin is altered after maximal exercise in highly trained male rowers. Eur J Appl Physiol, 2005; 93:502-505

12) Ferguson MA, White LJ, McCoy S, Kim HW, Petty T, and Wilsey J: Plasma adiponectin response to acute exercise in healthy subjects. Eur J Appl Physiol, 2004; 91:324329

13) Yokoyama H, Emoto M, Araki T, Fujiwara S, Motoyama K, Morioka T, Koyama H, Shoji T, Okuno Y, and Nishizawa Y: Effect of aerobic exercise on plasma adiponectin levels and insulin resistance in type 2 diabetes. Diabetes Care, 2004; 27:1756-1758

14) Marcell TJ, McAuley KA, Traustadottir T, and Reaven PD: Exercise training is not associated with improved levels of C-reactive protein or adiponectin. Metabolism Clinical and Experimental, 2005; 54:533-541

15) Tsukinoki R, Morimoto K, and Nakayama K: Association between lifestyle factors and plasma adiponectin levels in Japanese men. Lipids in Health and Disease, 2005; 4:27-35

16) Huang $H$, Tada-Iida $K$, Sone $H$, Yokoo T, Yamada N, and Ajisaka R: The effect of exercise training on adiponectin recdeptor expression in KKAy obese/diabetic mice. J Endocrinol, 2006; 189:643-653

17) Punyadeera C, Zorenc AHG, Koopman R, McAinch AJ, Smit E, Manders R, Keizer HA, Cameron-Smith D, and van Loon LJC: The effects of exercise and adipose tissue lipolysis on plasma adiponectin concentration and adiponectin receptor expression in human skeletal muscle. Eur J Endocrinol, 2005; 152:427-436

18) Zeng Q, Isobe K, Fu L, Ohkoshi N, Ohmori H, Takekoshi K, and Kawakami Y: Effects of exercise on adiponectin and adiponectin receptor levels in rats. Life Sci, 2007; 80:454-459

19) Lawler JM, Powers SK, Hammeren J, and Martin AD: Oxygen cost of treadmill running in 24-mo-old Fisher-344 rats. Med Sci Sports Exerc, 1993; 25:1259-1264

20) Kim MJ, Maachi M, Debard C, Loizon E, Clement K, Bruckert E, Hainque B, Capeau J, Vidal H, and Bastard: Increased adiponectin receptor-1 expression in adipose tissue of impaired glucose-tolelant obese subjects during weight loss. Eur J Endocrinol, 2006; 155:161-165

21) Chang SP, Chen YH, Chang WC, Liu IM, and Cheng JT: Increase of adiponectin receptor gene expression by physical exercise in soleus muscle of obese Zucker rats. Eur J Appl Physiol, 2006; 97:189-195

22) Fasshauer M, Klein J, Neumann S, Eszlinger $M$, and Paschke R: Adiponectin gene expression is inhibited by $\beta$-adrenergic stimulation via protein kinase $A$ in 3 T3-L1 adipocytes. FEBS Letters, 2001; 507:142-146 